\title{
EVALUASI POTENSI INTERAKSI OBAT ANTIBIOTIKA PADA PENYAKIT INFEKSI GASTROINTESTINAL PASIEN RAWAT INAP PERIODE JANUARI-JUNI 2016 DI RUMAH SAKIT IBNU SINA MAKASSAR
}

\author{
Irma Santi, Hendra Herman, Andi Afifatun Nisa Al Ishak \\ Fakultas Farmasi Universitas Muslim Indonesia, Makassar \\ Email: irma.santi@umi.ac.id
}

\begin{abstract}
Infective gastrointestinal is gastrointestinal tract inflammation (GIT), which is caused by microorganisms. The symptoms include diarrhea, vomit, abdominal pain, and fever. This study aimed to determine the antibiotic drug interaction potential based on the interaction mechanisms of gastrointestinal infectious diseases of in patients in the period of January to June 2016 at IbnuSina Hospital Makassar and to determine the severity of antibiotic drug interaction using the website www.drugs.com on the gastrointestinal infectious diseases. This research is non experiments conducted by dekskriptif method retrospectively. The results showed that the drug interaction in the therapeutic use along with less potential antibiotics to interact. This was shown that pharmacokinetic interaction mechanism is $3.80 \%$ cases and pharmacodynamics interactions is $6.33 \%$ cases, while the pharmacokinetic interaction instead of antibiotics is $40.51 \%$ cases, and pharmacodynamics interactions is $7.60 \%$ cases. Based on the minor or moderate severity levels, the drug interactions between antibiotics and other drugs are $11.39 \%$ cases while the drugs which is not the antibiotics of drug interaction case is $32.91 \%$ cases.
\end{abstract}

Key words : Drug interactions, gastrointestinal infections, Ibnu Sina Hospital.

\section{PENDAHULUAN}

Infeksi adalah invasi jaringan tubuh hospes oleh organisme penyebab penyakit, diikuti perbanyakan diri, dan reaksi jaringan hospes terhadap organisme atau racun yang dihasilkannya. Infeksi dapat disebabkan oleh agen infektif, antara lain virus, bakteri, jamur dan parasit. $^{1}$ Penyakit infeksi dapat didefinisikan sebagai penyakit yang dapat ditularkan atau cenderung disebarkan. ${ }^{2}$ Berdasarkan media/cara penularan yaitu: 1) melalui udara (Infeksi Saluran Pernafasan Akut/ISPA, pneumonia, dan TB paru); (2) melalui makanan, air dan lainnya (hepatitis, diare); (3) melalui vektor (malaria). ${ }^{3}$ Penyakit infeksi ini dapat menjadi penyebab utama morbiditas dan mortalitas di seluruh dunia. ${ }^{4}$
Antibiotik merupakan golongan obat yang paling banyak digunakan di dunia terkait dengan banyaknya kejadian infeksi bakteri. $\mathrm{Di}$ negara berkembang $30-80 \%$ penderita yang dirawat di rumah sakit mendapat antibiotik. Dari persentase tersebut $20-65 \%$ penggunaannya dianggap tidak tepat. ${ }^{5}$ Penggunaan obat dalam jumlah banyak juga dapat menyebabkan meningkatnya resiko pengobatan tidak tepat (interaksi obat dan duplikasi terapi), ketidakpatuhan dan efek samping obat. ${ }^{6}$

Interaksi obat terjadi jika efek suatu obat berubah akibat adanya obat lain, makanan, atau minuman. Interaksi obat dapat menghasilkan efek yang memang dikehendaki (Desirable Drug Interaction), atau efek yang tidak dikehendaki (Undesirable/Adverse Drug Interactions $=A D / s$ ) yang lazimnya 
Evaluasi Potensi Interaksi Obat Antibiotika Pada Penyakit Infeksi Gastrointestinal Pasien Rawat Inap Periode Januari-Juni 2016 Di Rumah Sakit Ibnu Sina Makassar

menyebabkan efek samping obat dan/atau toksisitas karena meningkatnya kadar obat di dalam plasma, atau sebaliknya menurunnya kadar obat dalam plasma yang menyebabkan hasil terapi menjadi tidak optimal. Misalnya Interaksi triazolam, midazolam (substrat) dengan ketokonazol, eritromisin (inhibitor) akan meningkatkan kadar substrat, meningkatkan bioavailabilitas (AUC) sebesar 12 kali, yang berakibat efek sedasi obat-obat sedatif di atas meningkat dengan jelas. ${ }^{7}$ Menurut Stokley's $(2005)^{9}$ mekanisme interaksi obat dapat dibagi menjadi interaksi farmakokinetik dan interaksi farmakodinamik. Kemudian level signifikansi interaksi ada 3 yaitu mayor, moderat dan minor. $^{8}$

Menurut data dari Rumah Sakit Ibnu Sina di Makassar, 10 penyakit terbesar pasien rawat inap Januari-Juni 2016, data yang didapatkan dengan jumlah terbanyak yaitu penyakit infeksi gastrointestinal (diare, dispepsia, dan demam tifoid). Berdasarkan hal tersebut di atas, maka pada penelitian ini dilakukan Evaluasi Interaksi Obat Antibiotik Pada Penyakit Infeksi Gastrointestinal Pasien Rawat Inap Periode Januari-Juni 2016 di Rumah Sakit Ibnu Sina Makassar.

\section{METODE PENELITIAN}

Penelitian ini merupakan jenis penelitian dekskriptif, dengan pengumpulan data secara retrospektif yaitu dengan melakukan penelusuran catatan pengobatan yang diberikan dokter kepada pasien rawat inap periode Januari-Juni 2016 di Rumah Sakit Ibnu Sina Makassar.

\section{Populasi Penelitian}

Populasi penelitian adalah seluruh pasien rawat inap dengan penyakit infeksi gastrointestinal periode Januari-Juni 2016 di Rumah Sakit Ibnu Sina Makassar.

\section{Sampel Penelitian ${ }^{10}$}

Sampel penelitian adalah data rekam medik pasien rawat inap dengan penyakit infeksi gastrointestinal periode Januari-Juni 2016 di Rumah Sakit Ibnu Sina Makassar yang memenuhi kriteria inklusi sebanyak 79 pasien.

\section{Kriteria Inklusi:}

1. Pasien dengan penyakit infeksi gastrointestinal diagnosa diare, dispepsia, dan demam tifoid dengan atau tanpa penyakit penyerta minimal 1

2. Pasien dengan terapi antibiotik

3. Pasien yang menggunakan lebih dari 1 terapi pengobatan

4. Pasien dengan data rekam medik lengkap dan menjalani perawatan periode JanuariJuni 2016

\section{Kriteria Eksklusi:}

1. Pasien dengan data rekam medik tidak terbaca

2. Pasien meninggal dunia

\section{Prosedur Kerja}

\section{Tahap persiapan}

Proses persiapan yang dilakukan sebelum pengambilan data yaitu pembuatan proposal, pembuatan surat perizinan untuk melakukan penelitian di Rumah Sakit Ibnu Sina Makassar, dan pengurusan Ethical Clearance kepada pihak Fakultas Kedokteran Universitas Hasanudin Makassar.

\section{Tahap pengambilan data}

Proses penelusuran data yaitu diambil data 10 penyakit terbanyak pada pasien rawat inap, setelah itu diambil satu penyakit yang paling banyak pada periode periode JanuariJuni 2016 di Rumah Sakit Ibnu Sina Makassar. Penelusuran data yang melalui sumber informasi data rekam medik, kemudian dilakukan pengelompokan lembar data Rekam Medik yaitu pasien dari periode Januari-Juni 
Evaluasi Potensi Interaksi Obat Antibiotika Pada Penyakit Infeksi Gastrointestinal Pasien Rawat Inap Periode Januari-Juni 2016 Di Rumah Sakit Ibnu Sina Makassar

2016 sesuai kriteria inklusi. Data pasien yang diambil yaitu data nomor rekam medik, identitas pasien dan diagnosis penyakit .

\section{Tahap pengolahan data}

Data yang diperoleh dikelompokkan dalam satu tabel yang terdiri dari nomor Rekam Medik, identitas pasien (jenis kelamin, umur), resep obat, dosis, rute penggunaan dan lama rawat inap.

\section{Analisis Data}

Karakteristik pasien yang meliputi nomor rekam medis, usia, jenis kelamin, lama perawatan, dan jenis obat yang diberikan, karakteristik tersebut diolah menjadi bentuk data tabel persentase. Data pemberian obat dianalisis menggunakan website Drug
Interaction Checker (drugs.com), kemudian dibandingkan dengan literatur EBM (Evidence Based Medicine) lalu dihitung jumlah kejadian interaksi obat, interaksi obat berdasarkan mekanisme, dan interaksi obat berdasarkan level signifikansi.

\section{HASIL DAN PEMBAHASAN}

Hasil evaluasi data rekam medis di Rumah Sakit Ibnu Sina Makassar periode Januari - Juni 2016 diperoleh data pasien rawat inap yang didiagnosa infeksi gastrointestinal (diare, dispepsia, demam tifoid) sebanyak 79 pasien. Hasil penelitian yang diperoleh disajikan dalam bentuk tabel sebagai berikut :

Tabel 1. Distribusi Jenis Kelamin Pasien Rawat Inap Infeksi Gastrointestinal (Diare, Dispepsia, Demam Tifoid) di Rumah Sakit Ibnu Sina Makassar periode Januari - Juni 2016

\begin{tabular}{ccc}
\hline Jenis Kelamin & Jumlah Pasien & Persentase (\%) \\
\hline Laki-laki & 37 & 46,83 \\
Perempuan & 42 & 53,16 \\
\hline Total & $\mathbf{7 9}$ & $\mathbf{1 0 0}$ \\
\hline
\end{tabular}

Tabel 2. Distribusi Kategori Umur Pasien Rawat Inap Infeksi Gastrointestinal (Diare, Dispepsia, Demam Tifoid) di Rumah Sakit Ibnu Sina Makassar periode Januari - Juni 2016

\begin{tabular}{|c|c|c|c|}
\hline Klasifikasi Umur (Tahun) & Tingkatan & Jumlah Pasien & Persentase (\%) \\
\hline $0-5$ & Balita & 1 & 1,27 \\
\hline $6-11$ & Anak-anak & 13 & 16,46 \\
\hline $12-17$ & Remaja & 9 & 11,39 \\
\hline $18-40$ & Dewasa & 40 & 50,63 \\
\hline $41-65$ & Tua & 15 & 18,99 \\
\hline$>65$ & Manula & 1 & 1,27 \\
\hline \multicolumn{2}{|l|}{ Total } & 79 & 100 \\
\hline
\end{tabular}

Tabel 3. Distribusi Lama Rawat Inap Pasien Infeksi Gastrointestinal (Diare, Dispepsia, Demam Tifoid) di Rumah Sakit Ibnu Sina Makassar periode Januari-Juni 2016

\begin{tabular}{ccc}
\hline Lama Rawat Inap (Hari) & Jumlah Pasien & Persentase (\%) \\
\hline $2-7$ & 63 & 79,75 \\
$8-10$ & 15 & 18,99 \\
$>11$ & 1 & 1,27 \\
\hline Total & $\mathbf{7 9}$ & $\mathbf{1 0 0}$ \\
\hline
\end{tabular}


Tabel 4. Distribusi Jenis Terapi Antibiotik Yang Diperoleh Pasien Rawat Inap Infeksi Gastrointestinal (Diare, Dispepsia, Demam Tifoid) di Rumah Sakit Ibnu Sina Makassar periode Januari - Juni 2016

\begin{tabular}{ccccc}
\hline Komposisi & Jenis Antibiotik & $\begin{array}{c}\text { Rute } \\
\text { Pemberian }\end{array}$ & $\begin{array}{c}\text { Jumlah } \\
\text { Kasus }\end{array}$ & Persentase (\%) \\
\hline & Cotrimoxazol & Oral & 2 & 2,44 \\
& Metronidazol & Oral & 1 & 1,22 \\
& Cefotaxim & IV & 1 & 1,22 \\
Terapi Tunggal & Ceftriaxon & IV & 49 & 59,76 \\
& Ciprofloxacin & Oral/ & 4 & 4,88 \\
& Levofloxacin & IV & 1 & 1,22 \\
& & Oral/ & 6 & 7,32 \\
& Cefixim & IV & 5 & 6,10 \\
& Amoxicillin & Oral & 7 & 8,54 \\
\multirow{2}{*}{ Terapi Kombinasi } & Oral & 1 & 1,22 \\
Antibiotik & Cotrimoxazol-Metronidazol & Oral-IV & 1 & 1,22 \\
& Gentamicin-Ceftriaxon & IV & 3 & 3,66 \\
& Ampicillin-Gentamicin & IV & 1 & 1,22 \\
\hline
\end{tabular}

Tabel 5. Distribusi Berdasarkan Mekanisme Interaksi Obat Pasien Rawat Inap Infeksi Gastrointestinal (Diare, Dispepsia, Demam Tifoid) di Rumah Sakit Ibnu Sina Makassar periode Januari - Juni 2016

\begin{tabular}{ccccc}
\hline $\begin{array}{c}\text { Mekanisme } \\
\text { Interaksi Obat }\end{array}$ & \multicolumn{2}{c}{ Jenis Obat } & Jumlah & $\begin{array}{c}\text { Persentase } \\
\text { Kasus }\end{array}$ \\
\cline { 2 - 3 } Farmakokinetik & Obat A & Obat B & & $(\%)$ \\
& Attapulgit & Ciprofloxacin & 1 & 11,11 \\
& Omeprazol & Ciprofloxacin & 1 & 11,11 \\
& Ampicillin & Gentamicin & 1 & 11,11 \\
\hline \multirow{3}{*}{ Farmakodinamik } & Cotrimoxazol & Metronidazol & 1 & 11,11 \\
& Ciprofloxacin & Loperamid & 1 & 11,11 \\
& Levofloxacin & Albuterol & 1 & 11,11 \\
& Cerftiaxon & Gentamicin & 3 & 33,33 \\
\hline & Total & & $\mathbf{9}$ & $\mathbf{1 0 0}$ \\
\hline
\end{tabular}

Tabel 6. Distribusi Berdasarkan Tingkat Keparahan (Signifikansi) Interaksi Obat Pasien Rawat Inap Infeksi Gastrointestinal (Diare, Dispepsia, Demam Tifoid) di Rumah Sakit Ibnu Sina Makassar periode Januari - Juni 2016

\begin{tabular}{|c|c|c|c|c|}
\hline \multirow{2}{*}{$\begin{array}{l}\text { Tingkat Keparahan } \\
\text { (Signifikansi) }\end{array}$} & \multicolumn{2}{|c|}{ Jenis Obat } & \multirow{2}{*}{$\begin{array}{c}\text { Jumlah } \\
\text { Kasus }\end{array}$} & \multirow{2}{*}{ Persentase (\%) } \\
\hline & Obat A & Obat B & & \\
\hline \multirow{2}{*}{ Minor } & Metronidazol & Cotrimoxazol & 1 & 11,11 \\
\hline & Omeprazol & Ciprofloxacin & 1 & 11,11 \\
\hline \multirow{5}{*}{ Moderate } & Ciprofloxacin & Attapulgit & 1 & 11,11 \\
\hline & & Loperamid & 1 & 11,11 \\
\hline & Levofloxacin & Albuterol & 1 & 11,11 \\
\hline & Ceftriaxon & Gentamicin & 3 & 33,33 \\
\hline & ampicillin & Gentamicin & 1 & 11,11 \\
\hline \multicolumn{3}{|c|}{ Total } & 9 & 100 \\
\hline
\end{tabular}

Pada penelitian ini karakteristik pasien seperti jenis kelamin, umur dan lama inap dirumah sakit dapat dilihat pada table 1, 2 dan

3. Sedangkan berdasarkan jenis pengobatan 
dan potensi interaksi yang terjadi dapat dilihat pada table 4, 5 dan 6. Berdasarkan pada tabel 1 diatas, menunjukkan bahwa pasien infeksi gastrointestinal rawat inap di RS. Ibnu Sina terdiri dari $46,83 \%$ pasien laki-laki dan $53,16 \%$ perempuan dimana jumlah pasien perempuan lebih banyak dari jumlah pasien laki-laki.

Berdasarkan pada tabel 2 diatas, diperoleh data pasien rawat inap infeksi gastrointestinal di RS. Ibnu Sina Makassar bahwa paling sedikit menderita penyakit infeksi gastrointestinal yaitu pada umur 0-5 tahun dan umur lebih dari 65 tahun $(1,27 \%)$. Hal tersebut disebabkan pada umur 0-5 tahun pasien lebih banyak menderita dehidrasi, sehingga jumlah pasien yang menggunakan antibiotik sangat sedikit. Dehidrasi akibat diare akut dengan etiologi apapun dan pada usia berapa pun, kecuali bila parah, dapat dengan aman dan diobati secara efektif oleh lebih dari $90 \%$ kasus dengan metode sederhana oral rehidrasi menggunakan cairan tunggal ${ }^{11}$.Sedangkan jumlah pasien yang paling banyak pada pasien umur 18-40 tahun (50,63\%). Umur pasien dapat digunakan untuk mengetahui banyaknya pasien infeksi gastrointestinal berdasarkan pemberian antibiotik yang tepat pada pasien, sehingga dapat memberikan efek yang optimal.

Berdasarkan pada tabel 3 diatas, menunjukkan kategori lama rawat inap pasien yaitu 2-7 hari sebanyak 63 pasien $(79,75 \%)$, 810 hari sebanyak 15 pasien $(18,99 \%),>11$ hari hanya 1 pasien $(1,27)$ Berdasarkan data tersebut lama rawat inap pasien yang diberikan terapi bersama antibiotik, paling banyak 2-7 hari.

Berdasarkan pada tabel 4 diatas, menunjukkan data terapi obat antibiotik yang diberikan pada pasien dengan antibiotik kombinasi yaitu kombinasi antibiotik paling banyak dari kombinasi antibiotik gentamicin dengan ceftriaxon. Pada penggunaan antibiotik tunggal bahwa penggunaan antibiotik tunggal yang paling banyak digunakan yaitu ceftriaxon IV.

Berdasarkan pada tabel 5 diatas, menunjukkan data interaksi obat farmakokinetik dan interaksi farmakodinamik dengan total sebanyak 9 kasus interaksi dari 79 pasien rawat inap. Interaksi obat dengan terapi bersama dengan antibiotik, terdapat 3 kasus $(3,80 \%)$ interaksi farmakokinetik yang terjadi. Interaksi tersebut yaitu (1) interaksi antara attapulgit dengan ciprofloxacin yang secara signifikan dapat mengurangi penyerapan golongan antibiotik kuinolon digastrointestinal, (2) interaksi antara omeprazol dengan ciprofloxacin; penyerapan ciprofloxacin sedikit berkurang $(20 \%)$ bila diberikan bersamaan dengan omeprazol, (3) interaksi antara ampicillin dengan gentamicin; menggunakan ampicilin bersama dengan gentamicin dapat mengurangi efek dari gentamisin. Interaksi farmakodinamik dengan terapi bersama antibiotik, terdapat 6 kasus $(7,60 \%)$ interaksi obat. Interaksi tersebut yaitu interaksi antara cotrimoxazol dengan metronidazol, ciprofloxacin dengan loperamid dan interaksi antara levofloxacin dengan albuterol; pemberian bersamaan dapat memperpanjang interval QT yang dapat mengakibatkan efek aditif dan peningkatan risiko aritmia ventrikel (torsade de pointes) dan kematian mendadak, sedangkan interaksi antara ceftriaxon dengan gentamicin; pemberian aminoglikosida dan sefalosporin dapat meningkatkan risiko nefrotoksisitas. ${ }^{12}$

Berdasarkan pada tabel 6 diatas, menunjukkan dari 79 data pasien rawat inap yang diberikan terapi bersama antibiotik 
dengan obat lain, hanya terdapat 9 kasus

$(11,40 \%)$ yang berinteraksi minor ataupun moderat. Interaksi obat potensial, yang menjadi perhatian utama adalah relevansi klinis atau signifikansi interaksi. Signifikansi berkaitan dengan jenis dan besarnya efek dengan perlunya pemantauan pasien atau mengubah terapi untuk menghindari konsekuensi yang berpotensi merugikan. ${ }^{13}$ Berdasarkan hasil yang didapatkan, interaksi antara antibiotik dengan obat lain sangat sedikit.

\section{KESIMPULAN}

Interaksi obat pada penggunaan terapi bersama antibiotik kurang berpotensial untuk berinteraksi. Hal ini ditunjukkan dari mekanisme interaksi farmakokinetik sebanyak $3,80 \%$ kasus dan interaksi farmakodinamik sebanyak $7,60 \%$ kasus. Berdasarkan tingkat keparahan minor ataupun moderat, interaksi obat antara antibiotik dengan obat lain yaitu sebanyak $11,40 \%$ kasus.

\section{DAFTAR PUSTAKA}

1. Soedarto. Mikrobiologi Kedokteran. Jakarta : CV.Sagung Seto, 2015.

2. Jenkins AJ and Valentine JL. Buku Ajar Interaksi Obat: Pedoman Klinis \& Forensik. Jakarta : EGC,2012.

3. Depkes RI. Riset Kesehatan Dasar. Jakarta : Badan Penelitian dan Pengembangan Kesehatan, 2013.

4. Cunha BA. Esensial Antibiotik Edisi 7. Jakarta : EGC, 2014.
5. Febrianto AW, Mukaddas A, Faustine I. Rasionalitas penggunaan antibiotik pada pasien Infeksi Saluran Kemih (ISK) di Instalasi Rawat Inap RSUD Undata Palu Tahun 2012. Jurnal of Natural Science. 2013;2(3):20-29.

6. Dewi CAK, Athiyah U, Mufarrihah, Nita Y. Drug therapy problems pada pasien yang menerima resep polifarmasi (Studi di Apotek Farmasi Airlangga Surabaya). Jurnal Farmasi Komunitas. 2014;1(1):1722.

7. Gitawati R. Interaksi obat dan beberapa implikasinya. Media Litbang Kesehatan. 2018;18(4):175-184.

8. Tatro DS. Drug Interaction Facts: The Authority on Drug Interactions, Facts and Comparisons. St. Louis, 2006.

9. Stockley IH. Stockley's Drug Interaction. Great Britain : The Pharmaceutical Press, 2005.

10. Dahlan SM. Besar Sampel dan Cara Pengambilan Sampel dalam Penelitian Kedokteran dan Kesehatan. Jakarta : Salemba Medika, 2010.

11. World Health Organization. The Treatment of diarrhoea : a manual for physicians and other senior health workers. 4th rev. Department of Child and Adolescent Health and Development, 2005.

12. Mara JC, and Carlos JT. Prevalence of potential drug-drug interactions and its associated factors in a Brazilian Teaching Hospital Brazil. J Pharm Pharm Sci. 2006;9(3):427-33.

13. Rahmawati F, Handayani R, and Gosal V. Kajian retrospektif interaksi obat di Rumah Sakit Pendidikan Dr. Sardjito Yogyakarta. Majalah Farmasi Indonesia. 2006;17(4):177-183. 